\title{
Micro-Doppler Ultrasonography-assisted Microsurgical Varicocelectomy: First Time in Turkiye
}

\section{Türkiye'de Illk Kez Mikro-doppler Ultrasonografi Yardımlı Mikrocerrahi Varikoselektomi}

\author{
(D) Ahmet Güdeloğlu, (D) Gökhan Karakurt, (D) Mesut Altan, (D) Ali Ergen \\ Hacettepe University Faculty of Medicine, Department of Urology, Ankara, Turkiye
}

What's known on the subject? and What does the study add?

According to our knowledge there is no report about intra-operative micro-Doppler ultrasound utilization during microsurgical varcicocelectomy procedure in Turkiye. This study demonstrates its first utilization, effectiveness and safety in our country.

\begin{abstract}
Objective: The magnification of the operative microscope or loop used in microsurgical varicocelectomy facilitates defining the anatomical structures. Even if the microsurgical approach is chosen, still, there is a 1\% chance of iatrogenic testicular artery ligation and this may lead to the testicular atrophy. In this study, our aim was to present the efficacy and safety of the micro-Doppler ultrasound (USG) used during microsurgical varicocelectomy for the first time in Turkiye.

Materials and Methods: A total of 46 patients with clinical varicocele underwent microsurgical varicocelectomy from May 2018 to July 2019. The da Vinci surgical system (CordaMed, İstanbul) was used in 5 patients and a standard operating microscope was used in 41 patients. Once the spermatic cord was brought up during the surgery, the velocity time integral microvascular Doppler system (Deltamed, Ankara) was used to identify the testicular vessels. The micro-Doppler USG probe allowed differentiation of the vessel by hearing the arterial pulsation audio.

Results: Microsurgical varicocelectomy was performed in 46 patients and 48 spermatic cord units. The mean number of spermatic veins that were ligated in each spermatic cord unit was 3.05 (2-5) and each spermatic cord unit had mean 1.4 (1-3) spermatic arteries that were preserved. The mean follow-up duration was 9 months and none of the patients developed testicular atrophy after the procedure.

Conclusion: The use of micro-Doppler USG in micro-surgical varicocelectomy seems to be an effective and safe method that facilitates the identification of testicular vessels. With the aid of micro-Doppler USG, even very small size arteries could be easily identified and iatrogenic damage could be avoided.
\end{abstract}

Keywords: Varicocelectomy, Microsurgery, Testicular arter injury, Micro-Doppler ultrasonography

Öz

Amaç: Mikrocerrahi varikoselektomide kullanılan ameliyat mikroskobunun veya loop gözlüğün büyütme özelliği anatomik yapıların tanımlanmasına yardımcı olsa bile \%1 oranında iyatrojenik testiküler arter bağlanması intimali mevcuttur ve bu durum testis kaybına kadar gidebilir. Bu çalışmada mikrocerrahi varikoselektomi ameliyatı esnasında ülkemizde ilk kez kullanılan mikro-Doppler ultrasonografi (USG) cihazının etkinliği ve güvenilirliği sunmak amaçlanmıştır.

Gereç ve Yöntem: Mayıs 2018 ile Temmuz 2019 tarihleri arasında klinik varikoseli olan toplam 46 hastaya mikrocerrahi varikoselektomi ameliyatı yapılmıştır. Beş hastada da Vinci Robotik Platform (CordaMed, İstanbul) kullanılmış, 41 hastada ise standart ameliyat mikroskobu kullanılmıştır. Ameliyat esnasında spermatik kord subinguinal insizyondan çıkarıldıktan sonra damarların tanımlanması aşamasında testiküler arter-internal spermatik ven ayrımında hız zaman integrali mikro-Doppler ultrason probu (Deltamed, Ankara) kullanılmıştır. Mikro-Doppler USG probu artere temas ettiği esnada işitsel yolla arteriyel pulsasyonun duyulması ile damar ayrımının yapılmasını mümkün kılmıştır.

Bulgular: Kırk altı hastanın 2'sinde bilateral olmak üzere toplam 48 spermatik kord ünitesine mikro-cerrahi varikoselektomi işlemi uygulanmıştır. Ameliyat esnasında kullanılan mikro-Doppler ultrason probu sayesinde testiküler arterler ve internal spermatik venler çok rahat bir şekilde tanımlanabilmiştir. Ameliyat esnasında ortalama 3,05 (2-5) spermatik ven bağlanmış ve ortalama 1,4 spermatik arter (1-3) korunmuştur. Ortalama

Correspondence: Ahmet Güdeloğlu MD, Hacettepe University Faculty of Medicine, Department of Urology, Ankara, Turkiye Phone: +90 3123051969 E-mail: a_gudeloglu@yahoo.com ORCID-ID: orcid.org/0000-0003-2927-9597

Received: 13.08 .2019

Accepted: 15.10.2019

Cite this article as: Güdeloğlu A, Karakurt G, Altan M, Ergen A. Micro-Doppler Ultrasonography-Assisted Microsurgical Varicocelectomy: First Time in Turkiye. J Urol Surg 2020;7(1):46-49.

๑Copyright 2020 by the Association of Urological Surgery / Journal of Urological Surgery published by Galenos Publishing House. 
takip süresi 9 ay olan hastaların \%67'sinde sperm parametrelerinde düzelme izlenmiş olup hiçbir hastada ameliyattan sonra testiküler atrofi izlenmemiştir.

Sonuç: Mikro-cerrahi varikoselektomi ameliyatında mikro-Doppler ultrason probu kullanılması testiküler arter ve internal spermatik ven ayırımını kolaylaştıran etkin ve güvenli bir yöntemdir. Mikro-Doppler ultrason probu sayesinde çok küçük boyuttaki arterler bile çok kolay tanımlanabilir ve ameliyat esnasında iyatrojenik hasardan kaçınılabilir.

Anahtar Kelimeler: Varikoselektomi, Mikrocerrahi, Testiküler arter hasarı, Mikro-Doppler ultrasonografi

\section{Introduction}

Today, various techniques from open to laparoscopic surgery, from microsurgery to percutaneous embolization have been defined for the repair of a varicocele which is accepted as the most common reversible reason of male infertility. Microsurgical approach has the lowest recurrence rate and the lowest postoperative complication rate and therefore it is preferred as the most efficient technique (1). The magnification of the operative microscope or loop used in microsurgical varicocelectomy facilitates defining the anatomical structures. Even if microsurgical approach is chosen, still, there is a 1\% chance of iatrogenic testicular artery ligation and this may lead to the testicular atrophy (2). Therefore, identification of the veins and arteries that are dissected and ligated during a varicocelectomy is very important.

The use of micro-Doppler ultrasonography (USG) in varicocelectomy surgery has been firstly identified in 2010 (3). It has been shown that more internal spermatic arteries were preserved and more spermatic veins were ligated when the micro-Doppler USG was used (3). According to the 2017 Public Hospitals Statistics Report, in only public hospitals, 37,000 varicocelectomy surgeries were performed in 2017 in our country (4). Despite this high number, to our knowledge, there have been no reports of the use of micro-Doppler USG in varicocelectomy surgery in our country. In this study, our aim was to present the efficacy and safety of the micro-Doppler USG used during microsurgical varicocelectomy for the first time in Turkiye.

\section{Materials and Methods}

The hospital ethical committe approval was obtained and the informed consent was signed by each patient before the surgery. A total of 46 patients with clinical varicocele underwent microsurgical varicocelectomy using a velocity time integral micro-Doppler USG probe (Deltamed, Ankara) from May 2018 to July 2019. The da Vinci surgical system (CordaMed, İstanbul) was used in 5 patients and a standard operating microscope was used in 41 patients.

The standard microsurgical varicocelectomy surgery principles were obeyed during the surgeries. An approximately 1-2 cm subinguinal incision was made and the spermatic cord was exposed and extracted to the surface through the incision. Then, depending on the joint decision of both the surgeon and the patient, the robotic platform or the surgical microscope was brought in and the microsurgical stage of the operation began. In this phase, initially the cremaster muscle was cut by cautery parallel to longitudinal axis of the spermatic cord. Then, with blunt and sharp dissections the vascular structures of the spermatic cord were identified. At this point, each vascular structure was examined several times by using the micro-Doppler USG probe and the artery-vein distinction was confirmed (Figure 1). The micro-Doppler USG probe allowed differentiating the vessel by hearing the arterial pulsation. All dilated veins were cut and ligated and the surgery was completed following the standard techniques.

\section{Results}

Microsurgical varicocelectomy was performed in 46 patients and 48 spermatic cord units. Indications for the surgery were: oligospermia in 29 patients, pain in 9 patients, pain and oligospermia in 6 patients, and azoospermia in 2 patients. The mean age of the patients was 27 years (18-47) and the mean duration of surgery was 38 (30-50) minutes. The testicular arteries and the internal spermatic veins were very easily identified with the assistance of the micro-Doppler USG probe

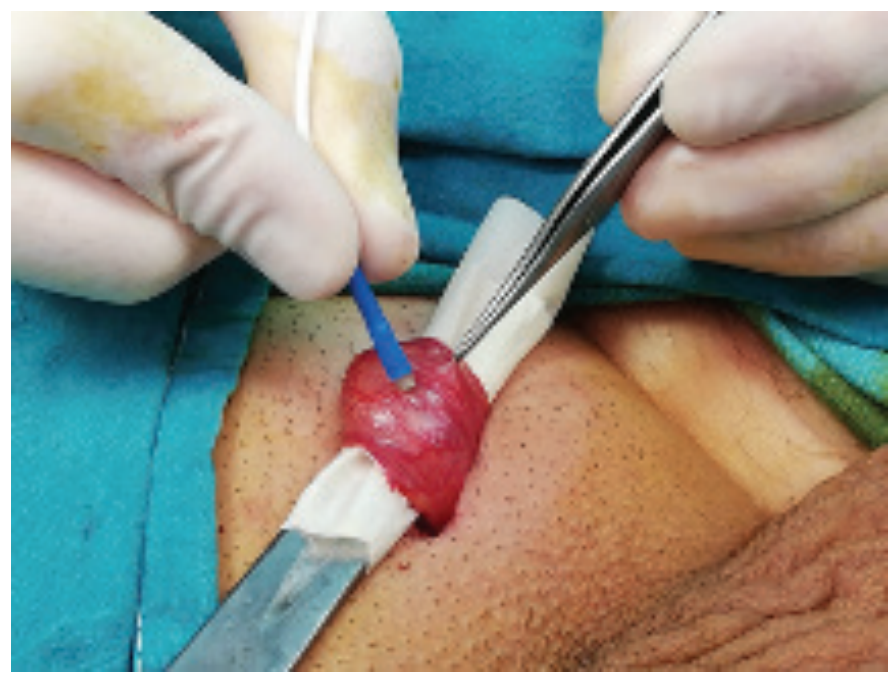

Figure 1. Use of intra-operative micro-Doppler ultrasonography 
used during the surgery. The mean number of spermatic veins that were ligated in each spermatic cord unit was 3.05 (2-5) and each spermatic cord unit had mean 1.4 (1-3) spermatic arteries that were preserved. The mean follow-up duration was 9 months and none of the patients developed testicular atrophy after the procedure.

\section{Discussion}

The European Association of Urology Infertility Guidelines recommends varicocelectomy in men with a clinical varicocele, oligozoospermia and otherwise unexplained infertility in the couple (5). It was shown in a meta-analysis that assessed randomized controlled trials comparing the current varicocelectomy techniques, patients operated via the microsurgical approach have higher pregnancy rates, lower recurrence rates and less postoperative hydrocele complications (1). The magnification of the operating microscope or loop used in microsurgical varicocelectomy clearly facilitates identifying the anatomical structures, however, it does not eliminate the iatrogenic testicular artery injury risk completely. In a retrospective study evaluating 2102 patients operated via microsurgical approach by using a surgical microscope providing magnification of $25 x$, it was shown that accidental ligation of the testicular artery occurred in $0.9 \%$ of the patients and testicular atrophy developed in 5\% of these patients with ligation of the testicular artery (2).

There may be many causes of the accidental artery ligation during microsurgery varicocelectomy (2). For example, smaller testicular arteries may not allow perceiving the arterial pulsation. In another theory, aggressive manipulations may cause arterial spasm and makes it difficult to identify the artery during dissection of the vessels. Another potential explanation is that the arteries may be present behind the complex branches of the veins or very close to them. Due to all of these potential risks, arteries may be accidentally ligated and testicular loss may occur.

In addition to the magnification of the operating microscope for the identification of the vessels in the spermatic cord during varicocelectomy procedure, urologists have been directed to other methods as well. In this context, Cocuzza et al. (3) first evaluated the value of systematic use of intraoperative Doppler USG during microsurgical subinguinal varicocele repair in 2010. In this study, 225 spermatic cord units that underwent microsurgical varicocelectomy by using micro-Doppler USG and 152 spermatic cord units that underwent microsurgical varicocelectomy without micro-Doppler USG were compared and it was shown that more veins were ligated ( 8.0 vs 7.3 ), more arteries were preserved (1.6 vs 1.3 ) and fewer arterial injuries were seen (0 vs 2 ) in the micro-Doppler USG group.
In a randomized controlled trial evaluating the use of intraoperative Doppler USG, surgical outcomes of 85 patients who underwent Doppler USG-assisted microscopic subinguinal varicocelectomy and and 87 patients without Doppler USG were compared. It was observed that the intraoperative Doppler USG group had shorter operative time (42 $\mathrm{min}$ vs $53 \mathrm{~min}$ ), greater number of protected arteries (1.9 vs 1.3 ) and greater number of spermatic veins ligated (7.8 vs 7.0) (6). Varicocelectomy is a very common surgery in our country. According to the statistical report made by the General Directorate of Public Hospitals in 2017, only in public hospitals, 2499 bilateral and 11957 unilateral varicocelectomy procedures were performed in Turkiye. (4). Considering the fact that private and university hospitals were not included in this report, the actual number of procedures would be way beyond these numbers. Considering the number of microsurgical varicocelectomies reaching tens of thousands a year and the probability of spermatic artery damage in $1 \%$ and resulting testicular atrophy in $5 \%$ of them, it may be estimated that tens of patients would suffer from complications leading to testicular loss due to a such simple operation as varicocelectomy. Therefore, as surgeons, it is our responsibility to take precautions in order to minimize the odds of these complications.

The use of intraoperative Doppler USG for the subinguinal microsurgical varicocelectomy procedure increases our knowledge about the anatomy of the spermatic cord. In a mapping study including 24 patients who underwent subinguinal varicocelectomy by using intraoperative Doppler USG, it was found that the mean number of ligated spermatic veins was 4.7 for each spermatic unit and $44.1 \%$ of these veins were found in the upper-medial quadrant of the spermatic cord (7). Similar to our study, the mean number of spermatic arteries was 1.33 for each spermatic cord in this study.

\section{Conclusion}

The use of operative microscope or surgical loops does not seem enough to protect accidental testicular arterial injury. The use of micro-Doppler USG in micro-surgical varicocelectomy seems to be an effective and safe method that facilitates identification of testicular vessels. With the assistance of micro-Doppler USG, even very small size arteries can be easily identified and iatrogenic damage can be avoided.

\section{Ethics}

Ethics Committee Approval: The hospital ethical committe approval was obtained.

Informed Consent: the informed consent was signed by each patient before the surgery.

Peer-review: Externally peer-reviewed. 


\section{Authorship Contributions}

Concept: A.G., A.E., Design: A.G., A.E., Data Collection or Processing: A.G., G.K., Analysis or Interpretation: A.G., M.A., Literature Search: A.G., A.E., Writing: A.G., M.A., A.E.

Conflict of Interest: No conflict of interest was declared by the authors.

Financial Disclosure: The authors declare that they have no relevant financial.

\section{References}

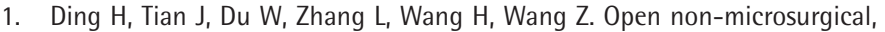
laparoscopic or open microsurgical varicocelectomy for male infertility: a meta-analysis of randomized controlled trials. BJU Int 2012;110:1536-42.
2. Chan PT, Wright EJ, Goldstein M. Incidence and postoperative outcomes of accidental ligation of the testicular artery during microsurgical varicocelectomy. J Urol 2005;173:482-4.

3. Cocuzza M, Pagani R, Coelho R, Srougi M, Hallak J. The systematic use of intraoperative vascular Doppler ultrasound during microsurgical subinguinal varicocelectomy improves precise identification and preservation of testicular blood supply. Fertil Steril 2010;93:2396-9.

4. Müdürlüğü KHG. Kamu Hastaneleri İstatistik Raporu 2017. 2017.

5. Jungwirth A, Giwercman A, Tournaye $H$, Diemer T, Kopa Z, Dohle G, Krausz C. European Association of Urology Guidelines on Male Infertility: The 2012 Update. Eur Urol 2012;62:324-32.

6. Guo L, Sun W, Shao G, Song H, Ge N, Zhao S, Liu Y, Zhang X, Xiao Z, Yuan M. Outcomes of Microscopic Subinguinal Varicocelectomy With and Without the Assistance of Doppler Ultrasound: A Randomized Clinical Trial. Urology 2015;86:922-8.

7. Juho YC, Wu ST, Kao CC, Meng E, Cha TL, Yu DS. Anatomic mapping of the internal spermatic vein via subinguinal varicocelectomy with intraoperative vascular Doppler ultrasound. J Chin Med Assoc 2019;82:115-9. 